\title{
THE GIREULAR ECONOMY IN THE STANDARDIZED MANAGEMENT SYSTEM
}

\author{
Magdalena Muradin ${ }^{1}$ and Zenon Foltynowicz ${ }^{2 *}$ \\ ${ }^{1)}$ Mineral and Energy Economy Research Institute of the Polish Academy \\ of Sciences, Kraków, Poland \\ ${ }^{2)}$ Poznań University of Economics and Business, Poznań, Poland
}

Please cite this article as:

Muradin, M. and Foltynowicz, Z., 2019. The Circular

Economy in the Standardized Management System.

Amfiteatru Economic, 21(Special Issue No. 13), pp.871-883.

Article History

Received: 22 August 2019

Revised: 8 September 2019

Accepted: 6 October 2019

\section{DOI: 10.24818/EA/2019/S13/871}

\begin{abstract}
The global depletion of non-renewable resources and climate change has lead scientists and politicians to change in the area of running modern economies. The best option currently seems to be the transition from a linear economy to a circular economy. However, there is no current agreed global vision on how to complete the circle. Therefore, it seems necessary to introduce a standard management system in the field of circular economy. The goal of this paper is to contribute with an overview of existing norms regarding circular economy and to assess the possibility of using them to create the ISO standards.
\end{abstract}

Keywords: circular economy CE, ISO standard, management system, BS 8001:2017, XP X 30-901

JEL Classification: Q5, O13

* Corresponding author, Zenon Foltynowicz - zenon.foltynowicz@ue.poznan.pl 


\section{Introduction}

For the first time since the invention of a steam engine, we are facing the huge challenge of humanity associated not only with the extensive use of resources and excessive pollution of the environment but also against global economic and social problems. In the nineteenth century, the society, while building economic prosperity, simultaneously contributed to the creation of an ecological crisis, treating the environment as an inexhaustible organism and a landfill that does not fill up. It was believed that economy was a closed and autonomous system, without links to other systems (Ciechelska, 2007). Finally, it was discovered that human well-being is built not only based on economic development but also, and perhaps above all, on the quality and durability of the natural environment. Only by maintaining the balance in nature, which we are a part of, will it improve the quality of human life. The first mention of the great threat of environmental degradation and the need to introduce immediate measures to improve it appeared in 1968 in the Report of the Club of Rome from 1969 (Meadows, 1973). The problem of sustainable development was defined, however, only in 1987 at the World Commission on Environment and Development, also called the "Brundtland Commission". Recently circular economy (CE) has been heralded as one of the most effective instruments for moving society towards sustainable development. A circular economy combines economic development with environmental protection and the efficient use of available resources (Foltynowicz, 2018). The core ideas of circular economy have emerged in the 1960s (Boulding, 1966). Other authors say that the CE concept has its beginning in the late 1970s (Geissdoerfer, et al., 2017). Several authors claim that the concept of circular economy has been introduced by Pearce and Turner in 1989 (Andersen, 2007; Su et al., 2013). The idea of a circular economy was strengthened when it was introduced in 2008 by Chinese decisionmakers in the Circular Economy Act in the People's Republic of China (Su et al., 2013) and then in the European Union (COM, 2015).

It was estimated that circular economy transitions by better use of resources can create more than 600 billion EUR annual economic gain for the manufacturing sector in UE alone (COM, 2014). Moreover, the Ellen MacArthur Foundation (2015) estimated that the implementation of circular economy until 2030 would allow creating a net economic benefit of 1.8 billion EUR and 2 million new jobs only in the European Union, which could also result in $48 \%$ reduction of anthropogenic $\mathrm{CO}_{2}$ emissions.

The CE concept combines economic development with environmental protection and rational management of resources. However, a circular economy should be considered mainly on the economic point of view, not environmental. The environmental protection and improving its quality should be the result of efficient management of resources, products, projects, and organizations consistent with the paradigm of circular economy. Only in that way, we can achieve real commitment of the whole society and the idea of circular economy will not remain as a theoretical approach only.

One of the best solution to implement a circular economy is to create standard requirements and guidelines for stakeholders. So far there are no comprehensive guidelines standardized even for European Union countries carrying the circular economy definitions, principles, strategies, implementation and monitoring. Only two countries of the European Union introduced national norms for circular economy; Great Britain with the circular economy standard BS 8001:2017 and France with standard XP X 30-901. 
Moreover, Millar, McLaughlin, and Börger (2019) argued that the exact relationship between Circular Economy and Sustainable Development has neither been thoroughly defined nor explored. Consequently, there are inconsistencies in literature showing how circular economy can serve as a tool for sustainable development, and incomplete understanding of how its long-term effects differ from those of "linear" economy (Millar, McLaughlin and Börger, 2019).

\section{Goal and scope}

The goal of this paper is to contribute with an overview of the English and French norms for circular economy and to assess the possibility of using them to create the ISO standard for circular economy. To find out if there is a real need for standardization of management system in the circular economy we have conducted a literature review. The next step was to analize and compare the norms BS 8001:2017 and XP X 30-901.

\section{Policy and legal documents for the circular economy}

One of the first regulations referring to circular economy appeared in China. The concept was introduced in the 1990s and formally accepted in 2002 by the central government as a new development strategy. Further details for specific sectors were provided with the implementation in 2009 of the Circular Economy Promotion Law (McDowall et al., 2017). The most important aim of this strategy was to raise the resource utilization rate and increase resource recovery in the whole loop of the product to achieve sustainability.

Another strategic step introducing the circular economy concept into wider awareness was the development of two documents by the European Commission "Towards a circular economy: A zero waste program for Europe" (COM, 2014) and "Closing the loop - An EU Action plan for the Circular Economy" (COM, 2015). The first one concerns mainly the reduction of waste generated at each stage of the product life cycle and the pursuit of Europe without waste, while the second document is focused on activities in the field of economics and closing the whole life cycle and the need to increase recycling levels. Document COM/2015/0614 indicates priority areas for action within sectors that face specific challenges in the context of circular economy. These are, inter alia, the sectors of plastics or critical raw materials. In the case of critical raw materials as well as plastics, a huge problem is the low level of their recovery and recycling. The problem is also wasting food at every stage of the value chain. Therefore, following the circular economy principles, the European Commission has decided to undertake many activities aimed at closing the circulation and the most effective use of resources supporting sustainable development. It is also worth mentioning the document from 2016, which is a summary of the meeting of the G7 environment ministers of the "Toyama Framework on Material Cycles", where, among other things, an action plan on promoting global resource efficiency or e-waste management has been adopted (Toyoma, 2016).

The synthesis of a major evolution of politics and law of the European Union has been recently presented in the recent Hannequart book (Hannequart, 2019). The author reviews the new strategic directions that European circular economy policy is bringing up, such as eco-design of products, eco-efficiency of production processes, product durability, greening of public procurement, innovative consumption, waste prevention, and new secondary raw materials 
market, the reduction of food wastage and the fight against marine pollution by plastics. The author also analyzes the new legal provisions in relationship withcircular economy, in particular, the revision of European waste directives, including reinforced prevention obligations, ambitious targets for recycling and more extended producer responsibility regime.

\section{The need for standardization of circular economy}

It seems that circular economy is a paradigm which will help society move towards sustainable development (EMAF, 2013). The current linear approach to the economy based on the assumption of "produce-consume-dispose" led to the situation of overexploitation of natural resources and environmental degradation, which in consequence may lead to irreversible degradation of our planet. The overriding goal of a circular economy should be to improve the economic conditions of society in such a way as to be beneficial for the environment. Only in this way can we achieve a high degree of implementation of the proposed rules on the use of existing resources in a closed cycle, in which waste generated in the production or consumption process will be reintroduced into the production cycle as a new potential material. This cycle should, therefore, be based on a few basic processes such as maintenance, repair, reusing, refurbishing, remanufacturing, redesigning, and recycling (EMAF, 2013). It seems that an important issue is firstly the introduction of uniform CE guidelines. The European standard of the CE management system would allow the establishment of a new level of its validity and unambiguous definition of the scope, purpose, principles, and mechanisms of activities in CE (Pauliuk, 2018). This is based on the fact that for the concept of circular economy there are more than 114 different definitions which were coded on 17 dimensions (Kirchherr et al., 2017). This results in a lack of consensus on terminology and CE definition among scientists, politicians, and practitioners studying trends, gaps and convergence of CE literature (Homrich et al., 2018). Kirchherr et al. (2017a) also pointed out that the most significant barriers of circular economy among others are lacking global consensus regarding CE transition support policy and lacking standardization generally. Even slightly different definitions of terms can, from a legal perspective, introduce misunderstandings and contradictory interpretations which may lead to differences in compliance with the CE principles.

The first standard definition of CE was provided by Ellen MacArthur Foundation (EMAF, 2013) as "a circular economy is an industrial system that is restorative or regenerative by intention and design". This definition has been implemented in many official documents, among others in the ISO 20400:2017 standard "Sustainable procurement - Guidance" as "economy that is restorative and regenerative by design, and which aims to keep products, components and materials at their highest utility and value at all times, distinguishing between technical and biological cycles". The definition adopted in the ISO standard largely clarified the situation, because many definitions of CE appeared in the literature. Kirchherr et al. (2017b) analyzed 114 definitions of the circular economy! An overview of the various CE definitions can be found in the review article by Masi et al. (2017). Masi et al. (2018) classified the most common definitions of CE into three categories:

- new label for an existing concept,

- a perspective set of existing concepts and practices,

- new definitions that go beyond previous approaches and seek to integrate economic, environmental and social issues. 
Korhonen, Honkasalo, and Seppala (2018) argued that the CE concept was mainly developed and led by practitioners and the scientific research content still remains unexplored. Due to this critical approach to the CE concept, they suggested new definition taking into account the three dimensions perspective (Korhonen, Honkasalo and Seppala, 2018): "Circular economy is an economy constructed from societal productionconsumption systems that maximize the service produced from the linear nature-societynature material and energy throughput flow. This is done by using cyclical materials flows, renewable energy sources and cascading-type energy flows. Successful circular economy contributes to all the three dimensions of sustainable development. Circular economy limits the throughput flow to a level that nature tolerates and utilizes ecosystem cycles in economic cycles by respecting their natural reproduction rates."

Another important aspect requiring unification is the method of measuring CE performance when its goals are so different from those used so far in linear economy. Potting, et al. (2016) asked, among other things, how to measure the progress of the transition towards a CE? The measure that allows the assessment of products and organizations in terms of their compliance with CE are circularity indicators. These indicators enable companies to adopt methodologies and tools to assess their activities and level of advancement in the transition from a linear economy to close-loop (Ellen MacArthur, 2013). Although in the last few years numerous indicators have been developed, they are inconsistent in their scope, objectives and possible applications (Saidani et al., 2019). Yet, the lack of academic and scientific knowledge on CE indicators is a barrier for further implementation (Akerman, 2016)

The conclusion is that there is a need to standardize the CE definition as well as the organization's activities in this area. This will contribute to obtain uniform CE standards and allow to conduct a comparative analysis of the results for individual organizations. There are also other aspects related to CE implementation, such as drivers, supporting elements and inhibitors of CE implementation, as well as the configuration of the circular economy supply chain (Masi, Kumar and Garza-Reyes 2018).

\section{Circular economy indicators}

The standardization is needed also for circular economy indicators. Worldwide, stakeholders agree that there is a need to launch CE-related measuring instruments (Saidani et al., 2019). If the feasibility of acircular economy has to be measurable the organizations should use the same indicators in the same way. Then the results will be comparable. Just as there is no single $\mathrm{CE}$ definition, there is also a problem with developing consistent $\mathrm{CE}$ indicators. It was found that 55 sets of $\mathrm{CE}$ indicators have been reviewed and classified about different purposes, scopes and potential usages (Saidani et al., 2019). It is crucial to know what the available indicators measure to use them properly (Saidani et al., 2019) and how to develop the assessment methods based on the use of indicators which can generate a deep understanding of the $\mathrm{CE}$. The lack of an unambiguous definition of $\mathrm{CE}$ means that some CE indicators can be interpreted in many different ways, as it is unclear what and how to measure. Finding the right indicators among all available ones can be difficult, but can be facilitated by the design of an appropriate classification scheme and associated selection tool (Saidani et al., 2019). 
Moraga et al. (2019) argue that CE indicators can be classified into three measurement scopes considering Life Cycle Thinking approach and modeling level. The standard for CE should provide the information about what and how to measure taking into account the $\mathrm{CE}$ definition and strategy which is grouped for the preservation of functions, products, components, materials and embodied energy (Moraga et al. 2019). On the other hand, the European Commission claims that CE cannot be measured by a single indicator and they gathered $\mathrm{CE}$ indicators in the following groups which can indirectly contribute to the Circular Economy development (Eurostat, 2019): sustainable resource management, societal behavior, and business operations. The transition to CE cannot be done without looking at eco-innovation as an integrated part of the circular economy. Smol, Kulczycka and Avdiushchenko (2017) proposed the CE-eco-innovation indicators divided into five different groups. It was pointed out that the CE indicators should be created based on an existing database and should be correlated with eco-innovation and regional policy indicators and include the whole life cycle of product or organization. For the EU and member state levels, the development of a $\mathrm{CE}$ monitoring framework is currently underway. To reduce the ambiguity of terms regarding flows and stocks, and then incompatible and misleading measurements, all indicators must be clearly defined and standardized (Pauliuk, 2018).

The European Commission set up a monitoring framework consisting of 10 indicators which were selected in order to capture the main elements of a circular economy (Eurostat, 2019). Half of those CE indicators come from Eurostat; others are produced by the Joint Research Centre (JRC) and the Directorate-General for Internal Market, Industry, Entrepreneurship and SMEs (DG GROW). The indicator of patents comes from the European Patent Office (EC). These 10 indicators, for which data is available in the database concern rather general and global level of implementing CE and are divided into the following four thematic areas: Production and consumption; Waste management; Secondary raw materials; Competitiveness and innovation (Eurostat, 2019).

However, without any standard for CE indicators, the implementation of the circular economy paradigm for many organizations causes differences in running CE projects. It can lead to difficulties in accurately assessing those projects when submitting application documents for a subsidy. Statistics on the implementation of CE in a given country or region will also be challenging.

\section{Existing norms and the possibility of implementation to the ISO standards}

So far two national norms in Great Britain and France regarding circular economy have been launched. "BS 8001:2017-Framework for implementing the principles of the circular economy in organizations-Guide" has been developed and launched in May 2017 by British Standards Institution (BSI), and after that in October 2018 French Standard Institute (AFNOR) launched the "XP X 30-901 - Circular economy - Circular economy project management system - Requirements and guidelines" There are certainly positive moves that bring the European Union and ISO closer together to develop a single harmonized standard for CE. In this article, we introduce a critical review and the comparison of those two norms which can help to answer the question if there is a possibility to close the circular economy in the frames of the standardized norm. In 2018 the ISO technical committee was initiated to elaborate the new standard for the circular economy, ISO/TC 
323. Members from over 65 different countries took part in a seminar organized by ANFOR, an ISO member from France, to initiate the idea of expressing the need to transition from a linear economy model to a circular economy. What followed was just a French standard, XP X30-901, that was published in 2018. ISO/TC 323, This standard aims to cover all aspects of a circular economy including public procurement, production and distribution, end of life as well as wider areas (such as a behavioral change in society), and assessment (such as some kind of circularity footprint or index) (Naden, 2019).

\section{The French Standard Institute norm}

The XP X30-901 standard contains a list of terms and definitions with particular regard to specific guidelines for management systems and sustainable development. It is a first CE standard which allows organizations to apply for certification that will attest to the project's circularity credentials. This document is applicable to organizations of all sizes, types, and natures. Consequently, the standard can be adapted to any type of project such as the development of a strategy, the supply of new services, the modification of a procurement, design or distribution process of a service or product (XP X30-901).

In the XP X30-901the terms and definitions regarding circular economy were described for the purposes of the document divided into two categories: specific to management system standards and specific to sustainable development and the circular economy. Many of the definitions were adapted from other norms for example from ISO 26000:2010. The standard contains also the definition of circular economy which varies from those previously known. The CE definition is described in table 2 of this article where it is compared with a definition taken from BS8001:2017. The French standard is based on the three sustainable development dimensions (XP X30-901):

- environmental - reduce the environmental impact,

- economic - increase resource-use efficiency,

- societal - improve the well-being of internal and external interested parties.

which are taken from the basis of the sustainable development paradigm and the seven circular economy areas of action concerned (XP X30-901) (table no. 1).

Table no. 1: The seven circular economy areas of action described in XP X30-901

\begin{tabular}{|l|l|}
\hline \multicolumn{1}{|c|}{ Area of action } & \multicolumn{1}{c|}{ Description } \\
\hline Sustainable procurement & $\begin{array}{l}\text { All environmental and societal impacts of the production } \\
\text { cycle of the resources should be taken into account. It } \\
\text { concerns the natural resource extraction and utilization } \\
\text { processes, acquisition of the components, non-renewable } \\
\text { raw materials replacement. }\end{array}$ \\
\hline Ecodesign & $\begin{array}{l}\text { Design of a product or a service, taking into account its } \\
\text { negative effects on the environment during its life cycle in } \\
\text { order to reduce them, while trying to preserve its qualities } \\
\text { or performance. }\end{array}$ \\
\hline
\end{tabular}

Vol. 21 • Special Issue No. 13 • November 2019 


\begin{tabular}{|l|l|}
\hline \multicolumn{1}{|c|}{ Area of action } & \multicolumn{1}{c|}{ Description } \\
\hline Industrial symbiosis & $\begin{array}{l}\text { It includes substitution synergies set up between several } \\
\text { economic players to optimize the use of resources and } \\
\text { pooling flows of materials and energy. The determining } \\
\text { factor in interrelations or pooling is geographical proximity. }\end{array}$ \\
\hline $\begin{array}{l}\text { Functional or service } \\
\text { economy }\end{array}$ & $\begin{array}{l}\text { It is dedicated to selling services rather than the products } \\
\text { and for fostering usage rather than ownership. }\end{array}$ \\
\hline $\begin{array}{l}\text { Responsible } \\
\text { consumption }\end{array}$ & $\begin{array}{l}\text { This applies to the changing of consumption practices and it } \\
\text { is based on the efficiency of informing the buyers and users } \\
\text { about environmental and social aspects of the product life } \\
\text { cycle. }\end{array}$ \\
\hline $\begin{array}{l}\text { Product lifetime } \\
\text { duration }\end{array}$ & $\begin{array}{l}\text { It results in the provision that the duration of a product or a } \\
\text { service be extended. }\end{array}$ \\
\hline $\begin{array}{l}\text { Efficient management of } \\
\text { end-of-life products and } \\
\text { materials }\end{array}$ & $\begin{array}{l}\text { It concerns all the techniques for transforming all types of } \\
\text { waste. Appears through transformation. }\end{array}$ \\
\hline
\end{tabular}

Particular attention needs to be paid to leadership, planning and operational activities. When launching a circular economy project all these areas have to be considered by an organization. The standard also provides guidelines and information about Leadership and commitment ensuring that all requirements and relevant management related to the $\mathrm{CE}$ are fulfilled in their respective areas. It is also important that the top management of an organization will establish the CE policy which will be adequate for projects launched in this organization.

The most valuable element of this standard seems the informative Annex A with examples of questions for each area of action divided into three core dimensions. The questions are also grouped into sub-items for example: sharing economy, life cycle, local ecosystem development of local skills and many more. Answering all these questions will allow the organization to set the project in the circular economy frames.

\section{The comparison of BS8001:2017 and XP X30-901}

The great advantage of BS8001:2017 is that it was a world's first standard on the circular economy and it makes Great Britain strongly positioned in this field (Pomponi and Moncaster, 2019). However, this standard provides only bits of advice and recommendations when XP X30-901 main content also consists of requirements for organizations on how to implement the $\mathrm{CE}$ for every kind of project launched in this organization. The standard contains an exhaustive list of CE terms and definitions, and a detailed record of economic, environmental, design, marketing and legal issues related to CE. The standard, however, has been criticized (Pauliuk, 2018) because it foresees that only organizations are responsible for choosing the appropriate CE indicators. It also does 
not discuss the links between monitoring the CE strategy and relevant and already standardized quantitative tools such as Life Cycle Asesment (LCA) and Material Flow cost Accounting (MFCA). Their significance as tools for monitoring the CE advances has been described, among others, by Haupt and Zschokke (2017) (for LCA) and by Pauliuk (2018), Zhou, et al. (2017) (for MFCA).

It seems that both standards are applicable for any type of organization, although Pomponi and Moncaster (2019) give some examples that the applicability of BS 8001:2017 is limited in the perspective of buildings. In XP X30-901 standard AFNOR provided a comprehensive explanation concerning two different terms and definitions specific to management system standards, sustainable development, and circular economy. The BS8001:2017 also supplies an extensive set of terms. However, for example, definitions of circular economy vary a lot. The definition of CE in XP X30-901 seems more versatile, detailed and adequate than the one in BS8001:2017. Especially the most significant part "the value of the products, materials, and resources is maintained in the economy for as long as possible and waste production is minimized" appears more rational (table no. 2). It is difficult to imagine in this contemporary and consumer economy a real zero waste approach. It is possible to minimize the amount of waste produced in the world but we cannot eliminate them completely. The British standard provides the CE definition more similar to this proposed by the Ellen McArthur Foundation. It is also worth emphasizing that CE definition in XP X30-901 standards contains the phrase concerning fostering individual well-being. It allows us not to depart from the contemporary approach that the human being is always at the center of all activities and first of all we have to care for the best existence of future generations in combination with the three pillars of sustainable development: environmental, economic and social aspects. This is also emphasized in this standard (XP X30-901).

Table no. 2: The comparison of the main factors of BS8001:2017 and XP X30-901

\begin{tabular}{|l|l|l|}
\hline \multicolumn{1}{|c|}{ Factor } & \multicolumn{1}{|c|}{ BS8001:2017 } & \multicolumn{1}{c|}{ XP X30-901 } \\
\hline main content & $\begin{array}{l}\text { guidelines, principles, flexible } \\
\text { framework }\end{array}$ & guidelines and requirements \\
\hline applicability & applicable to any organization & $\begin{array}{l}\text { applicable to any type of } \\
\text { project in an organization }\end{array}$ \\
\hline $\begin{array}{l}\text { circular economy } \\
\text { definition }\end{array}$ & $\begin{array}{l}\text { economy that is restorative and } \\
\text { regenerative by design, and } \\
\text { which aims to keep products, } \\
\text { components and materials at } \\
\text { their highest utility and value at } \\
\text { all times, distinguishing } \\
\text { between technical and } \\
\text { biological cycles }\end{array}$ & $\begin{array}{l}\text { exchange and production } \\
\text { which, at all stages of the } \\
\text { product (good and services) } \\
\text { life cycle aims to use } \\
\text { resources more efficiently } \\
\text { and diminish the } \\
\text { environmental impact while } \\
\text { fostering individual well- } \\
\text { being, and in which the value } \\
\text { of the products, materials, } \\
\text { and resources is maintained } \\
\text { in the economy for as long as } \\
\text { possible and waste } \\
\text { production is minimized. }\end{array}$ \\
\hline
\end{tabular}




\begin{tabular}{|c|c|c|}
\hline Factor & BS8001:2017 & XP X30-901 \\
\hline $\begin{array}{l}\text { end-purposes of } \\
\text { CE }\end{array}$ & $\begin{array}{l}\text { macro-level: improved } \\
\text { resilience of economic systems, } \\
\text { economic growth and } \\
\text { employment, preserved natural } \\
\text { capital and climate change } \\
\text { mitigation } \\
\text { micro-level: cost savings, new } \\
\text { resources of innovation and } \\
\text { revenue, improved customer } \\
\text { relationships, improved } \\
\text { resilience for organisations }\end{array}$ & $\begin{array}{l}\text { helping to reduce the } \\
\text { environmental impact of } \\
\text { development, increase } \\
\text { efficiency in the utilization of } \\
\text { resources and enhance the } \\
\text { well-being of the internal and } \\
\text { external interested parties. }\end{array}$ \\
\hline $\begin{array}{l}\text { circular economy } \\
\text { principles/areas of } \\
\text { action }\end{array}$ & $\begin{array}{l}\text { systems thinking, stewardship, } \\
\text { transparency, collaboration, } \\
\text { innovation, value optimization }\end{array}$ & $\begin{array}{l}\text { sustainable procurement, } \\
\text { ecodesign, industrial } \\
\text { symbiosis, functional or } \\
\text { service economy, responsible } \\
\text { consumption, product } \\
\text { lifetime extension, efficient } \\
\text { management of end-of-life } \\
\text { product and materials }\end{array}$ \\
\hline $\begin{array}{l}\text { scope of the } \\
\text { standard }\end{array}$ & $\begin{array}{l}\text { The generic guidance only for } \\
\text { monitoring and measurement. } \\
\text { The standard only stipulates that } \\
\text { organizations should "map the } \\
\text { system using relevant systems } \\
\text { thinking tools and techniques" }\end{array}$ & $\begin{array}{l}\text { wide and comprehensive } \\
\text { guidelines and requirements } \\
\text { concerning circular economy } \\
\text { project management system } \\
\text { including leadership, policy, } \\
\text { planning, and areas of action. }\end{array}$ \\
\hline
\end{tabular}

The six core CE principles in BS 8001:2017 that all organizations should refer to were described but there is not established any hierarchy among them. Pauliuk (2018) suggests that "system thinking" and "stewardship" can only have far-reaching consequences for decision-making within the organization. On the other hand, XP X30-901 highlights the principles of specific areas of operation. All those areas of action of the circular economy are explained comprehensively with examples in three dimensions: environmental, economic and societal. However, BS 8001: 2017 remains nonspecific. There is no information provided about the relationship between $\mathrm{CE}$ and these on-going transformation processes and their regulatory, political and scientific foundation (Pauliuk, 2018). The common relationship between sustainable development and circular economy which is widely discussed has been omitted in BSI standard as well.

The differences in those two investigated standards can be found also in the end-purposes of circular economy. Although they are similar, in BS 8001: 2017 those benefits are divided into two categories, at the macro and micro level. While in the French standard they are only in the macro dimension (Table 2). However, it should be emphasized that the latter standard sets the ultimate goal of "improving the well-being of internal and external stakeholders" as in the CE definition. This means that this issue has significant importance. 


\section{Conclusions}

It should be pointed out that the CE definition and indicators are only a few elements of the whole transition process to a circular economy. They create the frame of future development of CE, its improvement, measurement, and monitoring. The successful implementation of CE models is based on the key component at every stage of product or organization life cycle (EMAF, 2013).

It is evident that for continuous and sustainable development of circular economy, it is necessary to set uniform directions and methods of operation. The first positive step was the creation of the French standard XP X 30-901. Its assumptions are partly transposed to the international standard already prepared by the ISO committee, in which AFNOR will be a leader with extensive experience. The standard XP X 30-901 can provide a guide for sustainable development managers in implementing CE projects to ensure that the project contributes to CE implementation.

Comparing those two launched norms it can be concluded that the XP X 30-901 includes guidelines for all types of organizations. The CE definition presented in the XP X 30-901 is more comprehensive and seems more versatile and realistic to implement then the one in BS8001:2017. Nonetheless, it is a very important step towards putting CE into the framework of standards. Moreover, this AFNOR standard made them a leader in conducting the ISO circular economy standardization process. The implementation of the CE strategy requires new economic models on a global and local scale. All these changes must be economically, socially and environmentally sustainable to guarantee effective $\mathrm{CE}$ implementation in the long term (Saidani et al., 2018). We still have a long way to go in defining circular economy standards and their implementation globally, but the first step has already been taken. Now we are waiting for the next steps in this direction.

\section{Acknowledgments}

The authors would like to thank Mr. Tomasz Wojciechowski from GWDA sp. z o.o. for enabling the access to the XP X 30-901 standard.

\section{References}

AFNOR, French standard institute, 2018. French standard XP X 30-901, Circular economy - Circular economy project management system - Requirements and guidelines [online] AFNOR. Available at: <https://www.afnor.org/en/news/practical-guide-circulareconomy/> [Accessed 20 August 2019].

Akerman, E., 2016. Development of Circular Economy Core Indicators for Natural Resources - Analysis of existing sustainability indicators as a baseline for developing circular economy indicators. Master of Science Thesis, Royal Institute of Technology, Stockholm. Available at: <http://www.diva-portal.org/smash/get/diva2:897309/ FULLTEXT01.pdf> [Accessed 20 August 2019].

Andersen, M.S., 2007. An introductory note on the environmental economics of the circular economy. Sustainability Science, 2(1), pp.133-140. DOI 10.1007/s11625-006-0013-6

Boulding, K.E., 1966. The economics of the coming spaceship earth. In: H. Jarrett (ed.) 1966. Environmental Quality in a Growing Economy, pp. 3-14. 
British Standard Institution - BSI, 2017a. BS 8001:2017. Framework for Implementing the Principles of the Circular Economy in Organizations - Guide. London: BSI.

Ciechelska, A., 2007. Activities of financial institutions for the implementation of sustainable development. In: Kiełczewski, D., Dobrzańska, B.M. (ed.), Sustainable Development and Environmental Protection in the Economy. Bialystok: University of Economics in Bialystok.

Circular Economy Law of the People's Republic of China, 2008. Circular Economy Law of the People's Republic of China [online] Available at: <http://www.fdi.gov.cn/ 1800000121_39_597_0_7.html> [Accessed 23 August 2019].

Ellen MacArthur Foundation (EMAF), 2013. Towards the Circular Economy. [pdf] Ellen MacArthur Foundation. Available at: <https://www.ellenmacarthurfoundation.org/ assets/downloads/publications/Ellen-MacArthur-Foundation-Towards-the-CircularEconomy-vol.1.pdf $>$ [Accessed 21 August 2019].

European Commission, 2014. Towards a circular economy: A zero waste programme for Europe. [pdf] European Commission, Brussels. <https://ec.europa.eu/environment/ circular-economy/pdf/circular-economy-communication.pdf $>$ [Accessed 23 August 2019].

European Commission, 2015. Closing the Loop - An EU Action Plan for the Circular Economy. [pdf] European Commission, Brussels. <https://eur-lex.europa.eu/legalcontent/EN/TXT/?uri=CELEX:52015DC0614> [Accessed 12 August 2019].

EUROSTAT, 2019. Circular economy, Indicators. [online] Available at: <https://ec.europa eu/eurostat/web/circular-economy/indicators> [Accessed 23 August 2019].

Foltynowicz, Z., 2018. Circular solution to boost the sustainability. In: XXI IGWT Symposium - Sustainability, Quality and Innovation: A Global View of Commodity Sciences. Roma, Italy, 20-25 September 2018. Roma: Università degli Studi di Roma Tre.

Geissdoerfer, M., Savaget, P., Bocken, N.M.P., Hultink, E.J., 2017. The Circular Economy - A new sustainability paradigm? Journal of Cleaner Production, 143, pp.757-768.

Hannequart, J.P., 2019. Circular Economy. The Political and Legal Ambition of the European Union. La Louvière: Le livre en papier.

Haupt, M., Zschokke, M., 2017. How can LCA support the circular economy? The International Journal Life Cycle Assessement, 22(5), pp.832-837.

Homrich, S.A., Galvão, G., Abadia, L.G, Carvalho, M.M., 2018. The circular economy umbrella: Trends and gaps on integrating pathways. Journal of Cleaner Production, 175, pp.525-543.

International Organization for Standardization (ISO), 2019. Circular economy. [online] Available at: <https://www.iso.org/committee/7203984.html> [Accessed 23 August 2019].

International Organization for Standardization (ISO), 2017. ISO 20400:2017 - Sustainable procurement - Guidance [online] Available at: <https://www.iso.org/standard/ 63026.html> [Accessed 23 August 2019].

Kirchherr, J., Piscicelli, L., Bour, R., Kostense-Smit, E., Muller, J., Huibrechtse-Truijens, A., Hekkert, M., 2017a. Barriers to the Circular Economy: Evidence From the European Union (EU). Ecological Economics, 150, pp. 264-272. 
Kirchherr, J., Reike, D., Hekkert, M., 2017b. Conceptualizing the circular economy: An analysis of 114 definitions. Resources, Conservation and Recycling, 127, pp.221-232.

Korhonen, J., Honkasalo, A. and Seppala, J., 2018. Circular Economy: The Concept and its Limitations. Ecological Economics, 143, pp.37-46.

Masi, D., Day, S. and Godsell, J., 2017. Supply chain configurations in the circular economy: a systematic literature review. Sustainability, 9, pp.1602-24.

Masi, D., Kumar, V. and Garza-Reyes, J.A., 2018. Towards a more circular economy: exploring the awareness, practices, and barriers from a focal firm perspective. Production Planning \& Control, 29, pp. 539-550.

McDowall, W., Geng, Y., Huang, B., Barteková, E., Bleischwitz, R., Türkeli, S., Kemp, R., Doménech, T., 2017. Circular economy policies in China and Europe. Journal Industrial Ecology, 21, pp.651-661.

Meadows, D.H., Meadows, D.L., Randers, J., Behrens, W.W., 1973. The Limits to Growth. Warsaw: State Economic Publishing House.

Millar, N., McLaughlin, E. and Börger, T., 2019. The Circular Economy: Swings and Roundabouts? Ecological Economics, 158, pp.11-19.

Moraga, G., Huysveld, S., Mathieux, F., Blengini, G.A., Alaerts, L., Van Acker, K., Meester, S., Dewulf, J., 2019. Circular economy indicators: What do they measure? Resources Conservation and Recycling, 146, pp. 452-461.

Naden, C., 2019. ISO News. Connecting the dots in a circular economy: a new ISO technical committee just formed. [online] Available at: <https://www.iso.org/news/ref2402.html> [Accessed 23 August 2019].

Pauliuk, S., 2018. Critical appraisal of the circular economy standard BS 8001:2017 and dashboard of quantitative system indicators for its implementation in organizations. Resources, Conservation and Recycling, 129, pp 81-92.

Pomponi, F. and Moncaster, A., 2019. BS 8001 and the built environment: a review and critique. Proceedings of the Institution of Civil Engineers - Engineering Sustainability, 172(3), pp. 111-114.

Potting, J., Hekkert, M., Worrell, E., Hanemaaijer, A., 2016. Circular Economy: Measuring innovation in product chains. The Hague: PBL Netherlands Environmental Assessment Agency.

Saidani, M., Yannou, B., Leroy, Y., Cluzel, F., Kendall, A., 2018. A taxonomy of circular economy indicators. Journal of Cleaner Production, 207, pp.542-559.

Smol, M., Kulczycka, J. and Avdiushchenko, A., 2017. Circular economy indicators in relation to eco-innovation in European regions. Clean Technologies and Environmental Policy, 19(3), pp.669-678.

Su, B., Heshmati, A., Geng, Y., Yu, X., 2013. A review of the circular economy in China: moving from rhetoric to implementation. Journal of Cleaner Production, 42, pp.215-227.

Toyama Framework on Material Cycles, 2016. Toyama Framework on Material Cycles [pdf] Available at: <https://www.mofa.go.jp/files/000159928.pdf> [Accessed 23 August 2019].

Zhou, Z., Zhao, W., Chen, X., Zeng, H., 2017. MFCA Extension from a Circular Economy Perspective: Model Modifications and Case Study. Journal of Cleaner Production, 149, pp. 110-125. 